\title{
The trajectory of hybrid and hydrogen technologies in North American heavy haul operations
}

\author{
Kevin Oldknow $^{1}$ (D) Kyle Mulligan $^{2} \cdot$ Gordon McTaggart-Cowan $^{1}$
}

Received: 15 February 2021/Revised: 4 June 2021/ Accepted: 8 June 2021/Published online: 5 July 2021

(C) The Author(s) 2021

\begin{abstract}
The central aim of this paper is to provide an upto-date snapshot of hybrid and hydrogen technology-related developments and activities in the North American heavy haul railway setting, placed in the context of the transportation industry more broadly. An overview of relevant alternative propulsion technologies is provided, including a discussion of applicability to the transportation sector in general and heavy haul freight rail specifically. This is followed by a discussion of current developments and research in alternative and blended fuels, discussed again in both general and specific settings. Key factors and technical considerations for heavy haul applications are reviewed, followed by a discussion of non-technical and human factors that motivate a move toward clean energy in North American Heavy Haul systems. Finally, current project activities are described to provide a clear understanding of both the status and trajectory of hybrid and hydrogen technologies in the established context.
\end{abstract}

Keywords Transportation P Propulsion · Hydrogen · Hybrid · Alternative fuels

Kevin Oldknow

koldknow@sfu.ca

Simon Fraser University, Surrey, BC, Canada

2 Canadian Pacific, Calgary, AB, Canada

\section{Introduction}

Worldwide, passenger and freight railway systems are moving together with the broader transportation sector to consider, evaluate, develop, and deploy alternative means of propulsion based on clean energy technologies in efforts to reduce emissions and adapt to continually evolving environmental regulations. Options for electrification and alternative propulsion technologies (i.e., versus diesel and diesel-electric) in railway systems include overhead catenary and third-rail electrification, battery-electric, hydrogen fuel cell (or more typically hydrogen hybrid, incorporating fuel cells and batteries) and alternative fuels in combustion [1].

It is important to note that there are already many longstanding overhead catenary (and third-rail) systems in operation, with approximately $25 \%$ of the world's railway lines electrified in this way [2,3]. This stands in contrast with (for example) passenger road vehicles in which electric vehicles (EVs) remain a relatively new development in mainstream use. Overhead catenary electrification remains the most energy-efficient approach in railways and has locally zero emissions (with net emissions being entirely dependent on the mode of power generation at the electricity plant). However, overhead catenary system deployment (e.g., as a replacement for diesel locomotives) involves substantial up-front investment and as such does not lend itself particularly well to stepwise deployment or use on low-traffic lines that will extend the payback horizon. In the context of this paper, it is also important to note that the fraction of railway lines that are electrified varies widely by geography internationally, with the proportion in North America being particularly small [2].

Battery-electric systems are a more recent development, involving on-train batteries in combination with recharging 
lines and/or stations. These systems have been enabled by recent developments in nickel- and lithium-based battery technologies, yielding substantial reductions in weight and volume alongside improvements in robustness over many cycles [3]. Currently, battery-electric systems are at an advantage over hydrogen-based alternatives with respect to maturity, emissions, and total cost of ownership; however, hydrogen hybrid systems have the potential for significantly longer autonomous operating ranges [4]. Thus far, testing and deployment of battery-electric systems have been largely limited to passenger rail systems; however, testing in the North American freight environment is now underway, particularly on the Burlington Northern Santa $\mathrm{Fe}$ (BNSF) Railway [3, 5]. The FLXdrive battery-electric system deployed on BNSF's GECX 3,000 locomotive is a lithium-ion cell-based system, expected to deliver $3,275 \mathrm{~kW}$ of tractive power, with the capacity to dispatch $2,400 \mathrm{kWh}$ of energy from a full charge [6]. It is predicted that the locomotive will be capable of delivering its full tractive output for approximately $30 \mathrm{~min}$, and as such it is anticipated that the locomotive will be used in consist with regular diesel-electric units to deliver power in targeted locations where reduced emissions and noise levels are particularly desirable.

Progress in developing and evaluating hydrogen fuel cell-based approaches for railway systems has largely been enabled by continued advances in the efficiency and energy density of proton exchange membrane fuel cells (PEMFCs). As described later in this paper, these types of systems tend to be deployed in a hybrid arrangement together with battery-electric storage, in order to allow for optimal efficiency in operating the fuel cell-based subsystem. In addition to these fuel cell-based approaches, the development of alternative and blended fuels provides a prospective means to incorporate hydrogen into the locomotive energy spectrum through more traditional combustion-based architectures [1]. This is also discussed in detail in the paper.

Despite these developments, it should be remembered freight rail is already a highly efficient means of transportation, e.g., as measured in terms of fuel consumed per tonne-km. This presents a significant hurdle for newer alternative technologies in demonstrating clear advantages without sacrificing payload efficiency or operating costs [2]. Additionally, in the case of hydrail, there is not yet mass-produced hydrogen available for transportation applications [3], and the argument could be made that other (intrinsically less efficient modes of transportation) should be a higher priority for development and deployment. Beyond the technical considerations, however, are many non-technical and human factors that play a highly important role in motivating forward progress.
The remainder of this paper places hybrid, hydrogen, and alternative fuel developments in the general context of North American road and rail transportation systems, followed by a discussion of hybrid and hydrogen-related developments in North American heavy haul freight operations specifically.

\section{Developments in hybrid and hydrogen technologies for transportation systems}

This section provides an overview of hybrid and hydrogen propulsion developments in both road and rail transportation systems, mainly focusing on the North American setting. For clarity, this section is subdivided into a discussion on hybrid powertrains, followed by hydrogen fuel cell powertrains (with road and rail transportation covered in each). In practical terms, there is overlap between these subsections as hydrogen fuel cells are often utilized as a subsystem within hybrid powertrain architectures.

\subsection{Hybrid powertrains}

\subsubsection{Hybrid powertrains in road transportation}

Light-duty vehicles have been the leading application for hybrid powertrains in road transportation. This growth responded to regulatory requirements for low-emission vehicles, slower than expected development of purely electric vehicles, and increasing customer demand to reduce fuel costs through lower fuel consumption. Various manufacturers, led by Honda and Toyota introduced massproduced HEVs in North America (Honda Insight, 1999; Toyota Prius, 2000). By 2019, HEVs (including plug-in hybrids) accounted for approximately $2.9 \%$ of total light vehicle sales, down from a peak of $3.5 \%$ in 2013 [7]. Full electric vehicles accounted for another $1.5 \%$ in 2019 , having grown from less than $0.1 \%$ in 2010 . With 500,000 vehicle sales spread over $\sim 15$ different manufacturers and more than 50 different models [7], it is clear that HEVs remain a niche market.

Hybrid drive technologies cover a wide range, from integrated starter-generators that avoid idling by stopping the internal combustion engine (ICE) when a vehicle is stationary, to full battery-electric vehicles (BEVs) equipped with a small engine to provide additional battery charging capacity (e.g., BMW I3). A detailed review of light-duty hybrid technology is outside the scope of this paper; however, many good references are available (e.g., [8]). As with many technologies, HEVs experience a typical trade-off between improved efficiency achieved with increased technical complexity vs. increasing capital costs 
relative to an equivalent non-hybrid light-duty vehicle (in North America, predominantly gasoline-fuelled ICEs).

HEVs are particularly well suited to low-load, transient cycles where there are significant opportunities for energy recovery and where idling and low-speed driving form a significant portion of the total duty cycle. This makes them particularly well suited for light-duty automotive applications, especially in 'city' driving. The added vehicle mass from the hybrid system, combined with reduced energyrecovery opportunities, results in a smaller benefit for HEVs in 'highway' driving. This is a driving factor behind a relatively low uptake of hybrid drive systems in long-haul commercial trucking, where HEVs have not made significant penetration.

To drive efficiency improvements in long-haul commercial trucking in North America, the US Department of Energy (DOE) partnered with major commercial vehicle OEMs in the SuperTruck program [9]. The first phase, which ran from 2010 to 2015, saw 20 million USD provided to each of four OEMs (Daimler, Cummins, Navistar and Volvo) to investigate technologies to improve "freight efficiency" (ton-miles of freight transported per gallon of fuel consumed) by at least 50\% compared to each OEM's 2009 best-in-class vehicle. All four exceeded the target, with Daimler achieving a 115\% improvement, Cummins/ Peterbilt 86\%, and Volvo 88\% [10]. These results equate to fuel consumption reductions between $45 \%$ and $55 \%$ while transporting an equivalent payload compared to the 2009 baseline. A second phase (SuperTruck 2, 2016-2022) added PACCAR and targets an improvement in "freight efficiency" of $100 \%$ relative to that OEM's 2009 best-inclass vehicle. A key further requirement was that the technologies needed to have commercially viable payback periods of 2-3 years. Technology improvements have ranged from improved engine efficiency to reduced vehicle weight and low-rolling-resistance tires. Of relevance to rail applications, the engine and powertrain technologies have focused on improving engine efficiency, recovering energy from the waste heat in the engine exhaust and cooling system, and the potential to include a hybrid-electric powertrain.

In both SuperTruck programs, hybridization and energy recovery have been a key feature. While more advanced hybridization technologies were evaluated in SuperTruck, it was identified as a long-term technology $(5+$ years to commercialization [10]) that offered limited efficiency gains. A principal factor limiting HEV efficiency for longhaul trucks was that the typical duty cycle involves relatively few opportunities for dynamic energy recovery (regenerative braking). Further limitations include a need for the powertrain to provide near full load for extended durations, limiting the scope for efficiency gains by using a lower peak power ICE. Finally, the added weight of energy storage and electrified drivetrain and associated energy storage negatively impacted both economic viability and payload capability. This agrees with various European studies that concluded that hybridization for long-haul trucking offered limited $\mathrm{CO}_{2}$ benefit (2\%-4\% lower, or an equivalent fuel consumption saving) at the highest cost per unit $\mathrm{CO}_{2}$ saved for all the technologies assessed [11, 12].

In SuperTruck 2, all the OEM teams have converged on what would be considered a 'mild' hybrid approach. This is based on a $48 \mathrm{~V}$ DC electric system with a small ( 5-15 $\mathrm{kWh}$ ) battery. Electrification of auxiliaries (e.g., power steering pump, coolant pump, fan, air compressor) combined with an integrated starter-generator (ISG) reduces parasitic load and engine idling. Most are installing the ISG at the power-take-off on the vehicle transmission [13-16], such that powertrain energy can be recovered, but the ability to apply electric energy directly to the driveshaft is limited. Critically, in all cases, the $48 \mathrm{~V}$ system is coupled with waste energy recovery using various exhaust heat recovery systems (primarily organic rankine cycle (ORC) $[14,16])$. Estimates suggest that brake thermal efficiency (BTE) improvements of 3-5 percentage points (i.e., $6 \%-10 \%$ reduction in energy use) are possible from these combined systems. As such, they are a key contributor to the total engine system efficiency target for all the teams of $55 \%$ peak BTE; of the teams, Cummins/Peterbilt is already claiming $53.5 \%$ BTE on the engine system and are projecting to achieve a $170 \%$ improvement in "freight efficiency" (i.e., a reduction in fuel consumption exceeding 60\%) [15].

Most studies in both Europe and North America on hybridization for long-haul transport find that hybrid technology is not sufficiently beneficial. Some European interest in "last-mile" full-electric drive capability remains, primarily in response to restrictions on dieselfueled vehicles in city centers. More generally, technology in heavy-duty on-road trucking is advancing rapidly, with new trucks from major OEMs on track to achieve "freight efficiencies" $100 \%$ better than they were in 2010: these represent a reduction in fuel consumption (and associated $\mathrm{CO}_{2}$ emissions) on the order of $50 \%$. These are achieved through higher engine fuel economy (peak BTE's are likely to exceed 50\%) and improved vehicle systems. These improvements may pose a substantial challenge to rail, as advances in long-haul trucking efficiency might erode the efficiency benefit that is one of the major advantages of rail transport for goods.

\subsubsection{Hybrid powertrains in rail transportation}

Locomotive hybridization has held a long history within the North American rail industry and has evolved in many forms. A significant example which altered the industry has 
been the conversion from steam to diesel-electric locomotives which is still the primary means of motive power today [17] (see Fig. 1). Notable efforts in hybridization have been employed in order to increase the efficiency of diesel-electric locomotives. Locomotive "gensets" have been developed and employ multiple prime mover (engine) configurations which are activated and deactivated based on power demand. Gensets have been utilized in both yard and road power operations. A configuration utilizing multiple engines of varying power outputs is used to reduce fuel consumption and emissions by matching engine operating and power requirements to actual locomotive duty cycles. This is practical given that switcher and road locomotives in North America are idling between $70 \%$ and $80 \%$ and using full power between $0.3 \%$ and $1.7 \%$ of total operating time. Calculated duty cycles by throttle notch (i.e., N1-N8) for switcher and road locomotives are provided in Table 1 [18].

More recent hybrid locomotives have employed the use of batteries as opposed to increasing the number of onboard diesel engines to balance and support varying power demands. A notable example is known as the "Green Goat" or Railpower GG20B developed in September 2004 [19]. Although not designed for high horsepower applications, this locomotive utilizes a diesel generator in unison with a large battery bank to create a total of $1490 \mathrm{~kW}$ tractive power which is equivalent to a typical North American locomotive switcher. The locomotive has also been used in local over the road switching operations. The expansion of the GG20B concept using fuel cells and improved battery technology are discussed later in the paper. Also discussed are the challenges in the evolution of hybridization in rail beyond diesel generators which have been primarily limited by several factors including, but not limited to, fuel cells, battery technology, DC/DC

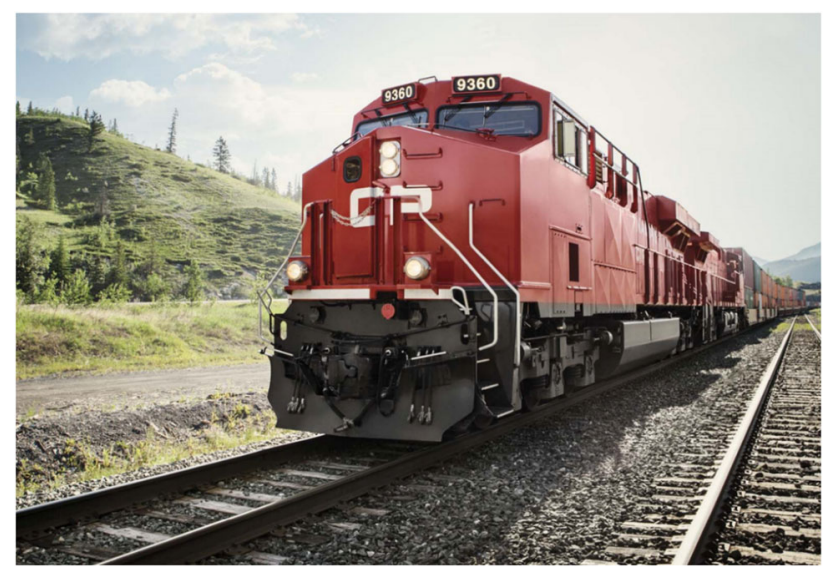

Fig. 1 Typical diesel-electric road locomotives (two head-end $3,275 \mathrm{~kW}$ AC units shown) in mainline usage on Canadian Pacific conversion and other electrical components. Typical advancements of the required hybridization components have been performed in the automotive industry (as described above), but the power requirements between the industries are vastly different.

\subsection{Hydrogen fuel cell powertrains}

\subsubsection{Hydrogen fuel cell powertrains in road transportation}

Fuel cells have a long history of development for on-road vehicle applications. In the heavy-duty sector, fuel cellpowered transit buses have been widely used in demonstration fleets in North America and Europe. Extension into the commercial truck market has been limited but is starting to see significant interest with OEMs, including demonstration projects involving Toyota, Navistar, and Freightliner (Daimler) [20-22]. This interest is driven in part by the recognition that payload and range requirements along with the need to avoid long recharging periods makes long-haul trucking particularly challenging for batteryelectric operation [23]. Fuel storage space is a practical concern for fuel cell electric trucks (FCETs) as well, due to the low energy density of $\mathrm{H}_{2}$. Recent work has suggested that for most heavy-duty truck applications, a combination of frame-rail and back-of-cab storage tanks should offer sufficient range [24], although this analysis appears to have been limited to gross vehicle weight ratings (GVWRs) less than $24,000 \mathrm{~kg}$, which precludes a significant fraction of the on-road long-haul tractor-trailer fleet in North America.

Part of the motivation for pursuing FCET development is that they can eliminate tailpipe greenhouse gas (GHG) emissions. Some studies have suggested this benefit compared to diesel in medium duty and regional service, even if the $\mathrm{H}_{2}$ is produced from natural gas via steam methane reforming (SMR) [25]. This was mainly due to higher efficiency of FCETs over urban cycles with significant transient operation, where modelling results suggested FCET energy efficiencies were $\sim 1.7$ times those of diesel. At loaded cruise $(90-105 \mathrm{~km} / \mathrm{h})$, the efficiency benefit of FCETs was only $\sim 1.2$ times [25]; although not reported, this likely means an increase in GHGs for long-haul applications if the $\mathrm{H}_{2}$ is sourced from SMR. This agrees with a European case study, which showed that while FCETs could replace any diesel-powered truck in Switzerland, the GHG impacts depended on $\mathrm{H}_{2}$ production: renewable, low-carbon sources generated GHG savings, but the use of SMR or grid electricity increased net GHG emissions [26].

$\mathrm{H}_{2}$ fuelled FCETs remain an emerging technology for on-road goods transport in North America. While the technology still needs to be proven, the involvement of 
Table 1 Calculated duty cycles by throttle notch for switcher and road locomotives in North American freight railway usage [18]

\begin{tabular}{llllllllll}
\hline Locomotive & Idle $(\%)$ & N1 (\%) & N2 (\%) & N3 (\%) & N4 (\%) & N5 (\%) & N6 (\%) & N7 (\%) & N8 (full power) (\%) \\
\hline Switcher & 80.7 & 7.3 & 6.3 & 3.1 & 1.4 & 0.5 & 0.3 & 0.1 & 0.3 \\
Road & 71.4 & 7.7 & 6.9 & 4.8 & 2.8 & 1.5 & 0.8 & 0.5 & 1.7 \\
\hline
\end{tabular}

major OEMs in collaboration with fleet operators and fuel cell technology providers in multiple demonstration projects suggests significant potential for widespread commercial deployment. Coupled with growing demand for low-GHG $\mathrm{H}_{2}$ generation, this offers a potential route for near-zero GHG goods transportation over the long distances that are typically the preserve of diesel-powered trucks or rail.

\subsubsection{Hydrogen fuel cell powertrains in rail transportation}

Developments in hydrogen fuel cell-based approaches for railway systems (often referred to as hydrail in the literature) have largely been enabled by continued advances in the efficiency and energy density of PEMFCs. Hydrogen hybrid arrangements allow these fuel cells to run in efficient near-steady-state operation, with batteries accommodating rapid changes in power demanded by traction systems. As with battery-electric systems, this arrangement also allows for the battery subsystem to capture dynamic braking energy in a regenerative approach; however, it should be noted that limitations in battery charge rates still require the dissipation of some braking energy through resistor banks in practical operating conditions.

Hydrail has seen significant reported progress in passenger rail, with highly visible demonstration systems deployed (e.g., [27, 28]), as well as some small-scale commercial deployments [3, 29]. In freight rail systems, the progress has been less visible, although there has been a development deployment of fuel cell-based switching and mining locomotives [3]. Later in this paper (see Sect. 6, below) significant initiatives in hydrogen hybrid technology for mainline use in North American heavy haul freight are reported and discussed.

\section{Developments in alternative and blended fuels for transportation systems}

Currently, diesel engines dominate goods transportation, from rail to marine to on-highway trucking. Their combination of high torque output at low speed, superior durability, and high efficiency are well suited to such extended duration, high-fuel use applications. In on-road trucking, technological advances have significantly increased peak
BTEs, which now exceed $46 \%$ in current best-in-class engines $[16,30]$, with an achievable goal of exceeding $50 \%$ using commercially viable technology in the 2022-2024 timeframe $[14,15])$. On-road applications have also had to address criteria pollutant emissions including nitrogen oxides $\left(\mathrm{NO}_{x}\right)$ and particulate matter (PM) (e.g., Euro VI [31], US EPA 2010 [32]). Additionally, on-road commercial vehicles are being required to significantly reduce GHG/ $\mathrm{CO}_{2}$ emissions (including US Phase 2 GHG [33] and EU $\mathrm{CO}_{2}$ regulations [34]) through engine and vehicle system efficiency improvements. The use of alternative, low-carbon fuels is also expected to contribute to meeting these standards. These innovations in the on-road sector may pose a challenge to rail's existing efficiency advantage, further motivating rail systems to improve efficiency and reduce GHG emissions without substantial cost increases.

Historically, interest in alternative fuels for goods transportation has been driven by fuel price. When diesel prices have been high, such as in the period 2010-2014, interest in lower-cost fuels has increased. More recently, increasing realization of the need to transition to low net GHG motive power is driving further interest in low-carbon fuels. A variety of alternative fuels have been proposed and evaluated in rail applications, including natural gas and biodiesel. The use of $\mathrm{H}_{2}$ is also an intriguing option despite its low volumetric energy density. The need to meet both economic and GHG requirements imposes a particular challenge.

Technology development to use alternative fuels has been undertaken by engine manufacturers and Class 1 railroad companies. Biodiesel is considered a near drop-in replacement for diesel; natural gas requires engine modifications, additional storage volume, and infrastructure development. Hydrogen is particularly intriguing: while much recent work has focused on fuel cell electric powertrains, the addition of $\mathrm{H}_{2}$ to a diesel engine offers significant near-term potential for GHG reductions and the option of reverting to conventional diesel fuelling in cases of scarce $\mathrm{H}_{2}$ supply. For all of the alternative fuels, both fuel cost and net GHG emissions (including upstream and end-use emissions) need to be considered. Figure 2 provides an indication of relative GHG intensities for different fuel sources, based on certified 'carbon intensities' (CIs) for on-road fuels under California's low-carbon fuel 


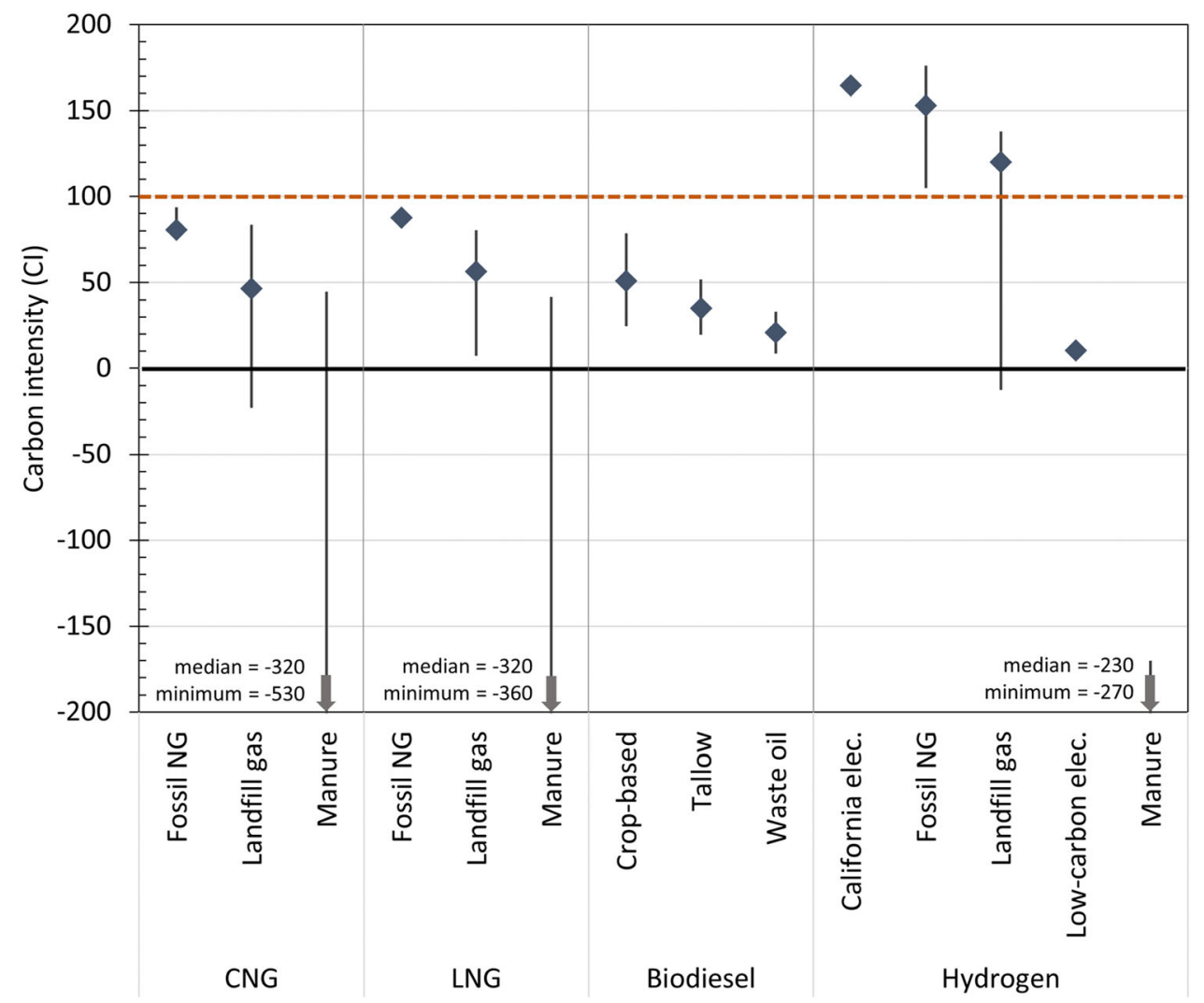

Fig. 2 Certified carbon intensities for selected fuels and suppliers, where 100 is the carbon intensity for crude-oil derived diesel on a well-towheel basis. Markers denote median value; range of certified values is shown by length of bars. Results include a $20 \%$ increase in energy consumption for compressed natural gas (CNG)/liquified natural gas (LNG) and a 35\% decrease in energy consumption for $\mathrm{H}_{2}$ relative to diesel. Derived from [35]

standards [35]. These carbon intensities represent the full life-cycle emissions of the fuel, relative to a diesel vehicle $(\mathrm{CI}=100)$, including tailpipe (i.e., end-use) emissions. They incorporate fuel conversion efficiencies taken for a representative California on-road vehicle fleet, which may not be representative of mainline rail applications.

From a practical viewpoint, both the space required to store the fuel and the net impact on vehicle mass are critical considerations when dealing with alternative fuels. Both natural gas (NG) and $\mathrm{H}_{2}$ are low-density vapors in standard conditions; they must be either compressed or liquified for storage. The energy densities for these alternative fuels are compared in Fig. 3 on both gravimetric and volumetric bases. The gravimetric data include estimated mass of the storage system. The volumetric data does not include storage system due to a lack of reliable data; however, both compressed and cryogenic storage systems are expected to require $20 \%-30 \%$ more volume than required for the density of the fluid itself. Both gravimetric and volumetric densities are based on the fuel's lower heating value (calorific content), excluding differences in fuel conversion efficiencies. NG and diesel are based on lower heating value; for $\mathrm{H}_{2}$, both lower and higher heating values are shown, representative of the chemical energy available for both internal combustion engines (LHV) and fuel cells (HHV). For compressed $\mathrm{H}_{2}$, storage densities at both 35 and $70 \mathrm{MPa}$ are shown; the general trend in the industry is toward $35 \mathrm{MPa}$ for commercial vehicles, while the $70 \mathrm{MPa}$ is focused on passenger car fleets.

\subsection{Biodiesel}

Biodiesel, a diesel-like fuel generated from biomass sources [36], offers significant net fuel-cycle GHG reductions as shown in Fig. 2. Typically, low-fraction blends of biodiesel are the primary focus: blends up to $5 \%$ by mass are equivalent to diesel and meet the ASTM D975 diesel fuel specification, while blends between $5 \%$ and $20 \%$ can be used with minor modifications to engine and fuel systems [36]. Net GHG benefits of such blends are limited considering the wide range of upstream $\mathrm{CO}_{2}$ emissions associated with biodiesel production shown in Fig. 2. Second- 


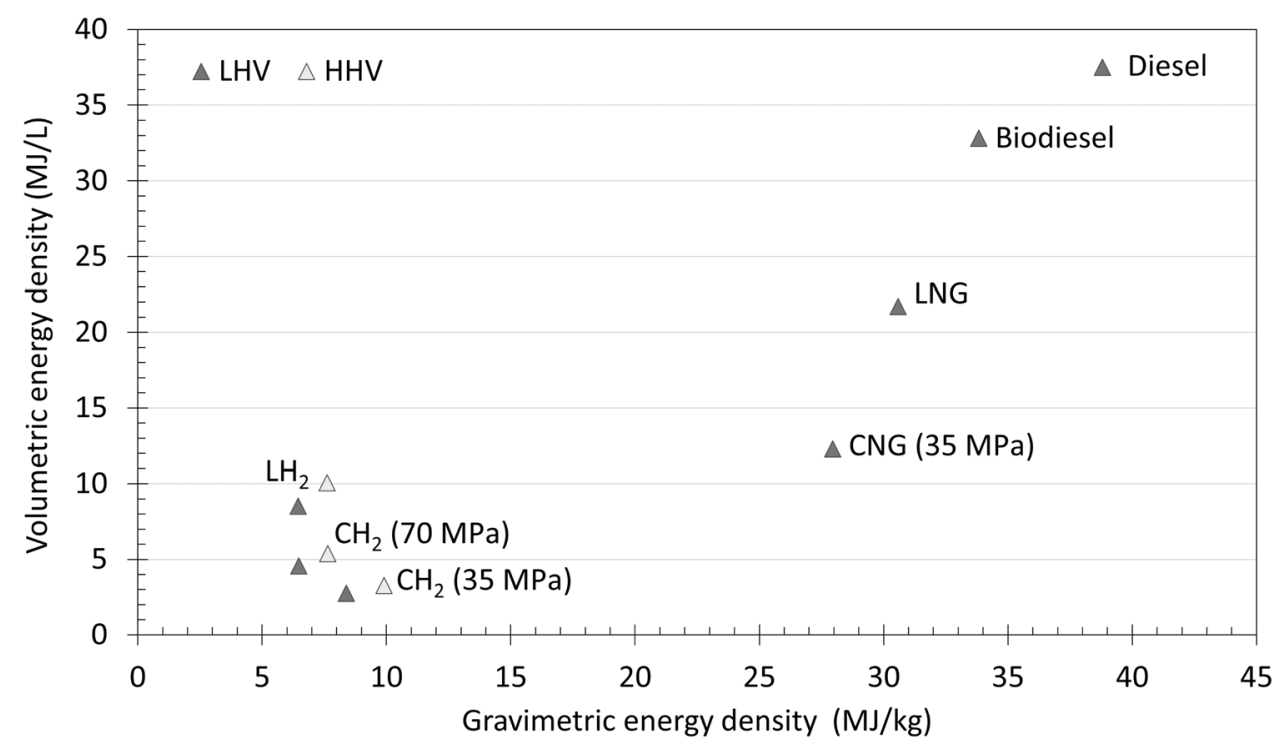

Fig. 3 Representative gravimetric and volumetric energy densities for selected alternative fuels. Gravimetric densities include the weight of the storage vessel and of the fuel itself. NG/diesel are shown on the basis of lower heating value (LHV); $\mathrm{H}_{2}$ is shown for both LHV (for IC engines) and higher heating value (HHV, for fuel cells). $\mathrm{LH}_{2}$ and $\mathrm{CH}_{2}$ stand for liquid hydrogen and compressed hydrogen, respectively

generation biofuels, such as produced from algae, can have relatively low upstream net $\mathrm{CO}_{2}$ and avoid displacing food crops [37]; but economically viable large-scale production of such fuels has not developed to date. Of the 180-odd biodiesel pathways currently certified by California Air Resources Board (CARB), only one derived from forestry waste does not involve food crops or food waste (tallow, cooking oil, etc.) [35].

Published studies of biodiesel use in rail locomotives have been conducted on older engines (e.g., EPA Tier$1+$ or Tier-2). These have identified that blends up to $20 \%$ were possible without impacting combustion or criteria air pollutant emissions but that the long-term impacts on fuel system hardware were uncertain $[38,39]$. The incremental cost of biodiesel blends is a significant consideration. Soybean-based biodiesel cost was estimated at $65 \%$ higher than No. 2 diesel fuel in 2014 (when diesel fuel prices were high) [38]. Other studies have found variability in biodiesel price with different feedstocks [40], but a consistent conclusion is that prices will generally be increased and that economics alone will not drive biodiesel use in rail even at blends of $20 \%$ or less. Assuming a median biodiesel CI of $30 \%$ (Fig. 2), and a $20 \%$ substitution ratio, this leads to a net GHG reduction of $14 \%$ compared to an equivalent diesel engine. Considering the limited acceptable levels of biodiesel blends, cost implications, and limited GHG benefits, biodiesel is likely an interim step in reducing the GHG impacts of long-distance rail transport.

\subsection{Natural gas}

An alternative fuel that is abundantly available in North America and has seen extensive research and evaluation for railroad use is natural gas (NG). To achieve acceptable volumetric energy densities, it is normally stored as cryogenic liquified natural gas (LNG). Potential fuel cost savings have long been recognized (e.g., [41]); these were a driving factor for Caterpillar and Electro-Motive Diesel (EMD) to pursue NG fuelling in 2010-2014 [42]. The fact that LNG produces on the order of $25 \%$ less $\mathrm{CO}_{2}$ than diesel fuel when burned on an energy-equivalent basis and produces lower emissions of criteria pollutant (particulate matter and $\mathrm{NO}_{x}$ ) were further benefits. On a life-cycle basis, North American LNG has a carbon intensity of $\sim 88 \%$ (Fig. 2) relative to diesel, when distribution, liquefaction and vehicle tailpipe emissions are included [35]. The CI calculated by CARB assumes an $\sim 20 \%$ fuel economy penalty for an NG engine compared to an equivalent to diesel, as well as relatively high methane emissions from both engine exhaust and crank-case ventilation. Technologies that more closely match diesel efficiency have been developed, and the most recent NG onroad commercial vehicle engines use closed crank-case ventilation and high-efficiency exhaust catalysts that can reduce vehicle $\mathrm{CH}_{4}$ emissions by $75 \%$ or more compared to the circa. 2010 engines used in the CARB life-cycle analysis.

Substantially greater GHG reductions can be achieved through renewable natural gas (RNG, derived from 
biological sources such as landfill or manure). The carbon intensity depends on the source, as shown in Fig. 2. Significant $\mathrm{CI}$ benefits can be realized through the use of waste to produce biomethane. Negative CI values occur when the collection, processing, and end-use of the fuel result in a net reduction in $\mathrm{CO}_{2, \mathrm{e}}$ compared to the case where no recovery was attempted. A critical limitation is that fuel prices of RNG are higher than for fossil NG, which is a particular barrier for highly fuel price sensitive applications such as rail.

Various technologies have been evaluated for railroad use that align closely with the NG combustion approaches used in on-road commercial vehicle engines. Specifically, three general approaches can be described, subdivided on how the fuel is introduced into the engine and then how it is ignited. Specifically:

- Premixed charge, spark-ignition (SI)

- Premixed charge, diesel pilot ignition ("Dual-fuel")

- Non-premixed charge, diesel pilot ignition with latecycle NG injection ("HDPI")

For railroad use, premixed charge spark-ignition engines were demonstrated in switching use, including four MK1200G LNG locomotives [43] for switching service in California. Other demonstrations include a recent Canadian Pacific-Bright Energy collaboration, where a separate SI NG auxiliary power unit (generator) was installed on a trailing rail car, with electric power transferred to a standard diesel-electric locomotive as shown in Fig. 4. CNG fuel storage was provided on board the same trailing car, along with a standard diesel power supply used to heat the generator to a minimum $38{ }^{\circ} \mathrm{C}$ (required prior to starting). It was anticipated that in future versions, the heater would also be CNG powered. While promising, such strategies based on lean-burn premixed charge spark-ignition engines had limitations including reduced power density compared to equivalent diesel engines. Other well-known limitations for such engines in the on-road market include high emissions of unburned methane $\left(\mathrm{CH}_{4}\right)$ and difficulty in controlling $\mathrm{NO}_{x}$ emissions. Current on-road technology in North America and Europe is focused on stoichiometric spark-ignition engines, which use a three-way catalyst for $\mathrm{CH}_{4}$ and $\mathrm{NO}_{x}$ control [44]. They also suffer from reduced efficiency and lower peak power than a diesel engine of equivalent displacement, eroding GHG benefits, fuel cost savings, and commercial suitability of the technology for mainline use in a conventional locomotive application.

Dual-fuel engines, which premix natural gas with air and then ignite the mixture with a small pilot injection of diesel, have been developed for locomotive, marine, and on-road trucking. In locomotive applications, both Progress Rail's DGB (dynamic gas blending) and GE's NextFuel ${ }^{\mathrm{TM}}$ use this approach [45]. For on-road applications, the technology was unable to meet Euro-VI emissions standards for $\mathrm{CH}_{4}(0.5 \mathrm{~g} / \mathrm{kWh})$, and hence the technology is not currently in widespread commercial deployment. Dual-fuel marine engines of a similar size to those found in locomotives have been commercialized in many jurisdictions. It is interesting to note that the EPA Tier-4 final rules specifically identify that for marine engines, $\mathrm{HC}$ emission limits exclude methane, which is a key factor enabling the use of this technology. Testing of marine dual-fuel engines has shown that tailpipe $\mathrm{CH}_{4}$ emissions can be extremely high, especially at low loads [46]: strategies for significant reductions are possible but the ability to meet Tier-4 HC emissions including $\mathrm{CH}_{4}$ will likely be very challenging. As $\mathrm{CH}_{4}$ has a global warming potential (GWP) of between 28 and 34 times that of $\mathrm{CO}_{2}$ on a 100-year time horizon [47], under loads below about $20 \%$ of full load the contribution of $\mathrm{CH}_{4}$ to the net GWP (in $\mathrm{CO}_{2, \mathrm{e}}$ ) exceeds that of the exhaust $\mathrm{CO}_{2}$ [46]. While these results are not necessarily representative of those seen in current railway locomotive engine technologies, the lean premixed NG

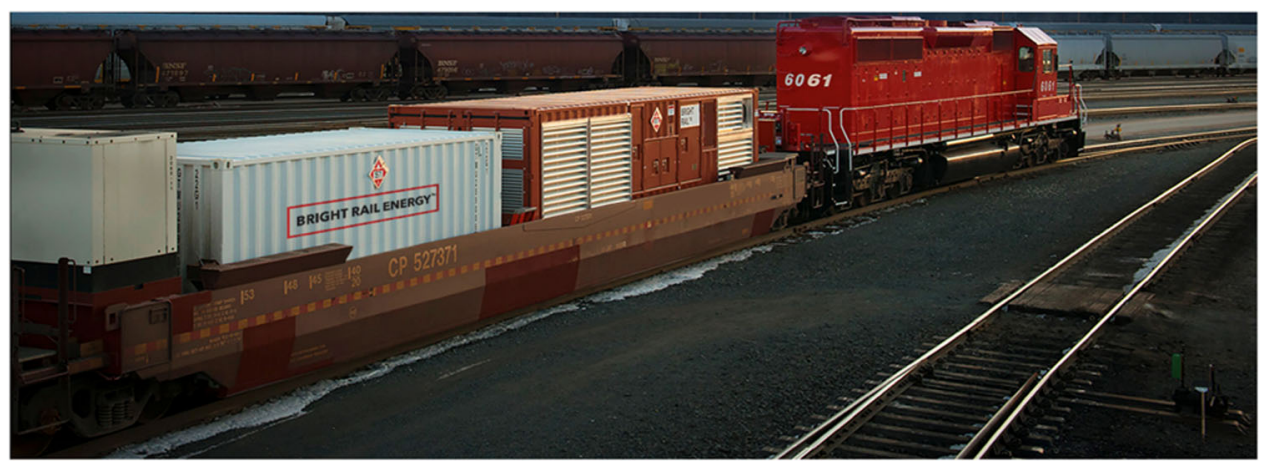

Fig. 4 Locomotive and trailing car arrangement (carrying fuel heating generator, CNG storage container, and auxiliary power unit) used in Canadian Pacific - Bright Energy collaboration 
combustion process will lead to $\mathrm{CH}_{4}$ emissions that make it very challenging to meet Tier $4 \mathrm{HC}$ standards.

For heavy-duty on-road applications, the highest power densities are provided by high pressure direct-injection (HPDI) of NG engines. Examples include the Volvo FHLNG [48], where a standard $13 \mathrm{~L}$ diesel engine is combined with a dedicated fuel system that supplies high pressure NG and diesel to the injectors through separate fuelling rails. HPDI engines follow a diesel-like non-premixed combustion process, with a small quantity of diesel injected first which then ignites the subsequent injection of natural gas [49]. HPDI has achieved Euro-VI emissions levels in heavy-duty truck engines up to $460 \mathrm{~kW}$, including $\mathrm{CH}_{4}$ emissions less than $0.5 \mathrm{~g} / \mathrm{kWh}$ on the certification test cycles [50], with tailpipe GHG emissions 15\%-20\% below an equivalent diesel [51]. For locomotives, South West Research Inc. (SWRI) developed a similar technology "LaCHIP" in the late 1990s [38]. More recently EMD worked with Caterpillar and Westport Innovations Inc. to investigate this technology; while promising, and still appearing on the Caterpillar web-site [52], there is no evidence of commercial deployment at this time. High substitution ratios $(90 \%-95 \%$ of the energy is from NG combustion) combined with diesel-like torque and efficiency [50] make the technology potentially attractive for high-fuel use applications where the fuel cost savings can offset the incremental price of the fuel system.

An operational limit for NG in rail applications is the need to store sufficient fuel. As shown in Fig. 3, both LNG and $\mathrm{CNG}$ require significantly more space than diesel on an energy-equivalent basis. As a result, on-locomotive storage for mainline use is currently infeasible, leading to a need to include a tender car. Examples developed by Westport Innovations [53] and by Chart Industries [54] involved an $\sim 38,000 \mathrm{~L}$ cryogenic ISO cylinder mounted on a custom platform car. This tender can be located between two locomotives and feed fuel to both, providing a reported $\sim 1,250 \mathrm{~km}$ range. To date, the tenders have only fed low-pressure NG to dual-fuel style engines; to provide fuel to an HPDI-style direct-injection engine, LNG compression would be needed, increasing system complexity and cost.

\subsection{Hydrogen-diesel dual-fuelling}

Hydrogen faces a critical limitation as a fuel in many applications: very low volumetric energy densities, as shown in Fig. 3. The energy input into either compression (to $35-70 \mathrm{MPa}$ ) or liquefaction (to $\sim 15 \mathrm{~K}$ ) add significantly to the net energy cost of the fuel [35]. Engines optimized and dedicated for $\mathrm{H}_{2}$ combustion would need to be substantially modified. Charge displacement by $\mathrm{H}_{2}$ 's low density will limit achievable power for lower-cost, premixed combustion systems. Direct-injection (DI) of $\mathrm{H}_{2}$ could avoid this; while significant technical development is needed, some commercial interest is developing [55]. Extending this to rail use is conceivable, as the technology being developed is similar to the DI natural gas fuel system tested by EMD in circa. 2014 [42].

A lower-cost option is to develop a $\mathrm{H}_{2}$-diesel dual-fuel combustion strategy for locomotive engines. Research focusing on heavy-duty on-road vehicles has suggested that the high flame speed of hydrogen can result in good efficiency and substitution ratios (energy from $\mathrm{H}_{2}$ /total energy released) of $90 \%$ at low loads [56]. Substitution ratios are significantly reduced at high loads: down to $\sim 30 \%$ at $70 \%$ of maximum load as increasing $\mathrm{H}_{2}$ content displaces charge air and increases the potential for pre-ignition [57]. $\mathrm{NO}_{x}$ emissions are also a potential limitation, as formation will tend to be increased with $\mathrm{H}_{2}$ fuelling [58] while exhaust gas recirculation will be less effective for $\mathrm{NO}_{x}$ control due to the increased $\mathrm{H}_{2} \mathrm{O}$ content in the exhaust. As current locomotives meet Tier- 4 without emissions after treatment, in-cylinder $\mathrm{NO}_{x}$ control will be needed-whether this is sufficient needs to be assessed.

The source of the hydrogen clearly has a significant impact on net GHG emissions, as shown in Fig. 2. For commercial trucking, using industry waste-product $\mathrm{H}_{2}$ in an unmodified commercial heavy-duty truck engine can lead to GHG emissions on the order of $50 \%$ while also providing fuel cost savings relative to conventional diesel [59]. Considering other sources, $\mathrm{H}_{2}$ generated from biomethane from manure has a highly negative carbon intensity. Conversely, $\mathrm{H}_{2}$ generated from steam methane reforming of fossil NG results in a net $\mathrm{CI}$ greater than for diesel. $\mathrm{H}_{2}$ generated by water electrolysis from California's current grid electricity is even worse (164\% that of diesel) [35]. Longer-term $\mathrm{H}_{2}$ from waste products such as manure, electrolysis from zero-carbon electricity, and industrial waste streams offer substantial GHG benefits [35]. Considering low-carbon electricity sourced $\mathrm{H}_{2}$, with a $50 \%$ substitution ratio and diesel-like efficiency, the net GHG reduction from a dual-fuel $\mathrm{H}_{2}$ engine would be on the order of $45 \%$.

The use of renewably generated hydrogen in an ICE offers a near-term path to reducing GHG from rail transport. Use as a supplemental fuel in an ICE also offers fuelflexibility as widespread $\mathrm{H}_{2}$ infrastructure deployment is as yet uncertain. Conversely, the potential benefits are limited by the higher cost of the fuel; without an efficiency benefit compared to diesel, $\mathrm{H}_{2}$ will likely increase net fuel costs while imposing operational limitations due to the need for a tender to carry the low-density fuel. High-efficiency powertrains, such as offered by fuel cells, offer inherent efficiency benefits that offer potential to offset the higher perunit energy fuel costs of $\mathrm{H}_{2}$, especially if coupled with 
Table 2 Comparative example of locomotive parameters in North American Heavy Haul (diesel-electric), European Freight (electrified), and European InterCity Passenger (electrified) systems

\begin{tabular}{llllll}
\hline Example model & \multicolumn{2}{l}{ Parameter (typical values) } \\
\cline { 2 - 6 } & $\begin{array}{l}\text { Rated locomotive } \\
\text { power }(\mathrm{kW})\end{array}$ & $\begin{array}{l}\text { Tractive effort, } \\
\text { starting }(\mathrm{kN})\end{array}$ & $\begin{array}{l}\text { Tractive effort, } \\
\text { continuous }(\mathrm{kN})\end{array}$ & $\begin{array}{l}\text { Weight }(\mathrm{t}) \\
\begin{array}{l}\text { Maximum } \\
\text { speed }(\mathrm{km} / \mathrm{h})\end{array}\end{array}$ \\
\hline $\begin{array}{l}\text { GE transportation ES44DC [2, 60] } \\
\begin{array}{l}\text { Bombardier transportation TRAXX } \\
\text { F140 MS2 [2, 61] }\end{array}\end{array}$ & 3,275 & 632 & 470 & 196 & 121 \\
Bombardier transportation & 5,580 & 400 & 300 & 85 & 140 \\
\hline
\end{tabular}

economic mechanisms (e.g., carbon pricing) for net GHG emissions.

\section{Technical factors and considerations in heavy haul systems}

The demands placed on locomotives in typical North American heavy haul operations create specific and unique challenges for the deployment of alternative energy derived approaches such as battery-electric and fuel cell systems. These are driven by uniquely difficult operating conditions including train lengths, trailing tonnages, track curvature, and ruling grades. For perspective, Table 2 provides example parameters relating to locomotive usage in North American Heavy Haul (diesel-electric), European Freight (electrified), and European InterCity Passenger (electrified) systems.

An early review of fuel cell locomotive feasibility in Canadian National's western high tonnage operations was carried out in the early 1990s [62], based on the prospect of deployment within 15-30 years. Considerations included hydrogen sources, onboard storage, range, duty cycles and the development of "smart" train technologies. The prospect of legislation requiring that anthropogenic $\mathrm{CO}_{2}$ emissions be incorporated into life-cycle costing was also anticipated. The study concluded that the fuel cell locomotives fell short of feasibility by approximately one order of magnitude, but suggested that feasibility was attainable in about 15 years based on targets for reductions in capital costs and improvements in performance.

More recently, the opportunity for $\mathrm{CO}_{2}$ emissions reductions in rail through the implementation of hydrogen fuel cell motive power (including heavy haul, based on data from Canadian National and Canadian Pacific) was compared to that for other transportation modes including road, air and marine using data for the province of Ontario [63]. Comparisons were generated based on ranges of hydrogen adoption (versus conventional fossil fuels), as well as hydrogen production mixes including electrolysis, copper-chlorine thermomechanical cycle, and SMR. It was found that the opportunities for $\mathrm{CO}_{2}$ emissions reductions were the largest in passenger vehicles (road vehicles less than $4,500 \mathrm{~kg}$ in weight) and rail.

It is important to also note that heavy haul operators in North American are publicly traded companies accountable to shareholders. In contrast to operators within Europe who are government owned or subsidized, shareholder accountability is important. Executives must balance economic factors with research and development initiatives around clean energy. Some of the challenges and motivations within the North American Heavy Haul systems are discussed in the following sections.

\section{Motivations for moving to hydrogen and hybrid technologies in North American heavy haul operations}

North American Class I railroads are progressively aligning emissions reductions goals to limit climate change with the Paris Agreement. In Canada, Class I railroads are also aligning with the Pan-Canadian Framework on Clean Growth and Climate Change. These initiatives seek to limit global temperature rise to well below $2{ }^{\circ} \mathrm{C}$ above pre-industrial levels [64]. Recent studies suggest that development of hydrogen uses is necessary in achieving these goals [65].

Relative to traditional electrification of locomotive propulsion using catenaries and/or third rails, hydrogen fuel cell systems for North American Heavy Haul systems are cited as more cost-effective [18] with the highest potential for clean energy. Some studies suggest that the initial capital costs of installing catenary systems in North America can exceed 27B USD per railroad (or over 200B USD for all North American railroads) when adjusted to 2020 values. These estimates do not include short lines. Given the capital costs and span of the transcontinental rail networks, overall catenary systems are seen as impractical 
for heavy haul operations without government subsidies as suggested in [66].

Factors such as, but not limited to, foreign investment in "green" or "B" corporations, increases in domestic carbon taxes, young workforce interests in green technologies, and adoption of fuel cells by the trucking industry (Alberta Zero Emissions Truck Electrification Collaboration [67]), are encouraging North American Class I railways to plan and invest sustainably. In Canada alone, carbon taxes are expected to rise $566 \%$ by 2030 [68]. With increasing investor and government pressures, railroads need to adopt greener technologies at accelerated rates.

Fuel reduction technologies to automate operator functions and improve engine components have been developed and implemented for decades within the North American rail industry to create more efficient diesel-fueled locomotives [69]. Although these technologies have improved fuel economies of heavy haul locomotives up to $20 \%$, emissions are still generated due to the use of diesel fuels and internal combustion as the primary means of electrical power generation for propulsion. Due to increasing regulation, alternative means such as hydrogen are required in order to avoid heavy penalties due to emissions generation. These penalties will ultimately result in unsustainable business costs negatively impacting railroad operating ratios.

Improvements in hydrogen fuel cells and batteries have provided promising alternatives to using diesel fuel and combustion. These technologies can also be used to convert existing platforms similar to modernization programs which are ongoing within the industry. Modernizations provide a viable business case for hydrogen versus electrification by enabling railroads the ability to extend sustainable amounts of capital over time through re-use of locomotive cores.

Hydrogen also provides the advantage of similar refueling times as compared to diesel refueling at similar costs. The average cost of diesel fuel within the North American rail industry is $0.71 \mathrm{USD} / \mathrm{L}$, or $2.67 \mathrm{USD}$ per US gallon [70]. One (1) $\mathrm{kg}$ of hydrogen is equivalent to approximately one (1) US gallon (3.78 L) of fossil fuel in energy content. Generation of hydrogen through oil and gas costs approximately 1.00-1.80 USD/kg. As discussed above, hydrogen generation from oil and gas can also be include carbon capture (i.e., "blue" hydrogen) costing 1.40-2.40 USD/kg [71]. Hydrogen derived through electrolysis using a renewable energy source (i.e., "green" hydrogen) can cost 2 to 3 times per $\mathrm{kg}$ versus oil and gas methods; however, these costs are dropping annually. It is important to note that the costs do not include the hydrogen infrastructure that would be needed for deployment in heavy haul operations. However, given the limited number of freight rail terminals, those located near refineries can have practical access to hydrogen through partnerships. Other benefits of moving toward clean energy sources within the industry include but are not limited to decarbonization of urban areas, noise reduction and mobile power sources.

\section{Status and trajectory of hydrogen and hybrid systems in North American heavy haul operations}

Development of hydrogen fuel cell-powered locomotives specific to the North American freight rail industry began as early as 1999 [72]. The initial locomotive demonstrators developed for the mining industry [73] use a non-hybrid architecture consisting of a PEMFC without the use of onboard batteries. Batteries have been incorporated in later design iterations to increase power and range while decreasing refueling times.

Deployments of mining locomotive demonstrators ultimately led into exploration of hydrogen-powered freight locomotives within the North American Class I railways. The first notable project started in 2003, is a "switcher" locomotive built in collaboration between the United States (US) Department of Defense, US Department of Energy, and the BNSF Railway (see Fig. 5). Switcher locomotives have been selected for initial fuel cell exploration based on analysis of duty cycles from locomotive event recorder downloads. On average, the power consumption of a switcher locomotive in North American operation is $75 \mathrm{~kW}$ (computed over a 20-h interval) [74] which aligns with the power output capabilities of fuel cell and battery combinations available on the market in 2003. Line-haul (road power) locomotives require up to 2.5 times more power than switcher locomotives. An important consideration when determining the feasibility of a freight locomotive hydrogen conversion is available space. Given the size versus power output of fuel cells and batteries in 2003, a line-haul locomotive conversion would not have been feasible.

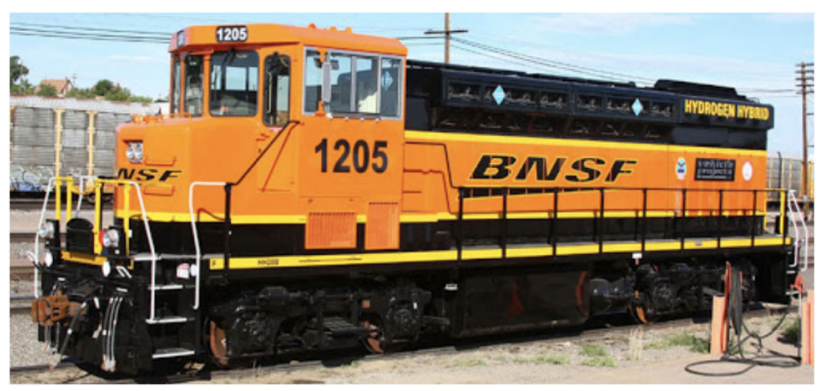

Fig. 5 Hydrogen hybrid switcher locomotive (RailPicture.net photo Nathan Zachman) 
Advances in power output of fuel cells and batteries versus physical footprint have enabled companies such as Canadian Pacific [75], to explore alternatives to diesel fuel for powering freight line-haul locomotives. The conversion pilot initially targets locomotives which utilize DC-powered traction motors. Unlike switcher locomotives, these motors require significantly higher voltages and currents which increases power management complexity. The main limiting factor in conversions due to the higher voltage and current requirements is revealed through DC-DC converters which are vital components in the power management process. As an example, off-the-shelf DC-DC converters are designed primarily for the automotive industry and regulate voltage on a DC-link (or DC-bus) limited to a maximum voltage output at $850 \mathrm{~V}$ and current draw of 400 A in most cases. Larger corporations which specialize in technology integration must integrate using components from other industries such as solar power in order to achieve the power requirements for line-haul locomotives.

Another reason the North American industry is exploring DC-powered line-haul locomotives first is due to internal knowledge. Typically, North American locomotive vendors support locomotives under contract maintenance. These agreements significantly limit the intellectual property (IP) sharing between the locomotive vendors and the associated Class I railroads. There is an abundance of knowledge around DC-powered locomotives in both literature and in the industry, which reduces the learning curve and initial costs for performing conversions. Future partnerships with AC-powered locomotive vendors may exist; however, as described above, there is a greater urgency being placed on the Class I railways for meeting emissions reductions targets. As such, the developments and deployments of these conversions are being driven by the Class I's.

\section{Summary and conclusions}

Transportation systems in general, and railways specifically, are working to evaluate, develop and deploy alternative propulsion technologies in pursuit of improved efficiencies, reduced GHG emissions, and compliance with environmental regulations that are evolving and tightening in response to climate change. In addition, fundamental energy efficiency will remain a competitive factor between transportation modes.

While much of the world's railway infrastructure is already electrified through overhead catenary or third-rail systems, there are significant portions of railway networks (particularly in North American freight operations) for which this type of electrification is not feasible. Other alternatives to diesel combustion that are being considered for locomotive propulsion in railway systems include battery-electric, hydrogen fuel cell hybrid (i.e., hydrail), and alternative fuels including replacements for diesel (such as biodiesel or natural gas), as well as blended fuels in which renewable alternatives are introduced alongside diesel in the combustion process.

Both hybrid powertrains and hydrogen fuel cell-based technologies have seen substantial improvement and development in recent years, driven in part by the fundamental technological platforms (high density batteries, and PEM fuel cells), as well as major projects and market developments in road vehicles (both light-duty passenger and heavy-duty freight). While these developments have helped to narrow the feasibility gap for use in railway systems, the specific and unique challenges associated with heavy haul rail operations require substantial additional development to realize the voltages, currents, powers and torques needed for line-haul deployment.

Alternative fuels provide a wide range of alternatives with respect to the underlying combustion technology, cost, energy density, and net GHG emissions. While energy density remains a fundamental challenge in many cases, there is a good chance that this approach will provide a viable interim solution for both road and rail transportation that helps to meet near-term and long-term emissions reduction targets. Within this domain, blended fuels also provide another approach through which hydrogen might be integrated into locomotive propulsion systems in heavy haul freight rail.

Presently there are battery-electric and hydrogen hybrid prototype systems in active development and evaluation within North American heavy haul railways. In the space of battery-electric drives, BNSF is testing a lithium-ion cellbased system capable of delivering full tractive power for approximately $30 \mathrm{~min}$, which is expected to enable targeted and specific use in reducing emissions and noise. In the domain of hydrogen and hybrid systems, Canadian Pacific is developing a hydrogen fuel cell-based hybrid system for evaluation, integrated into a standard dieselelectric locomotive platform. In the short term, the initiative will make use of a DC traction motor system, allowing for rapid development due to simplicity and an established knowledge base. Depending on the outcomes of initial evaluation, this platform may provide a path toward wider spread development and deployment.

Open Access This article is licensed under a Creative Commons Attribution 4.0 International License, which permits use, sharing, adaptation, distribution and reproduction in any medium or format, as long as you give appropriate credit to the original author(s) and the source, provide a link to the Creative Commons licence, and indicate if changes were made. The images or other third party material in this article are included in the article's Creative Commons licence, unless indicated otherwise in a credit line to the material. If material is not 
included in the article's Creative Commons licence and your intended use is not permitted by statutory regulation or exceeds the permitted use, you will need to obtain permission directly from the copyright holder. To view a copy of this licence, visit http://creativecommons. org/licenses/by/4.0/.

\section{References}

1. Petrunic J, Campbell R, Ludwig B, Gerster C, Hydrail: The future of rail electrification worldwide (2020) Canadian Smart Rail Technology Conference 2020 - CUTRIC, November 23-24, 2020, virtual, online

2. Zenith F, Isaac R, Hoffrichter A, Thomassen MS, Møller-Holst S (2020) Techno-economic analysis of freight railway electrification by overhead line, hydrogen and batteries: Case studies in Norway and USA. Proc Inst Mech Eng Part F J Rail Rapid Transit 234:791-802

3. Thorne R, Amundsen A H, Sundvor I (2020) Battery electric and fuel cell trains: maturity of technology and market status. Institute of Transport Economics, Norwegian Centre for Transport Research. https://www.toi.no/getfile.php?mmfileid=52027. Accessed 30 Dec 2020

4. Adams A (2020) Leading the way in hydrogen. Railw Gaz Int 176:32-33

5. Railway Gazette International (2018) BNSF and GE to test battery loco. Railw Gaz Int 174:10

6. McDonnell G (2020) Battery-electric breakthrough. Trains Magazine special edition: Locomotive 2020. 2pp

7. Davis S, Boundy R (2020) Transportation energy data book: edition 38.2. Prepared for Vehicle Technologies Office, US DOE, by Oak Ridge National Laboratory. www.tedb.ornl.gov. Accessed 6 Feb 2021

8. Singh KV, Bansal HO, Singh D (2019) A comprehensive review on hybrid electric vehicles: architectures and components. J Mod Transp 27(2):77-107

9. Delgado O, Lutsey N (2014) The US Supertruck Program-expediting the development of advanced heavy-duty vehicle efficiency technologies. The International Council on Clean Transportation. https://theicct.org/sites/default/files/publications/ ICCT_SuperTruck-program_20140610.pdf. Accessed 18 June 2021

10. Department of Energy (2016) Supertruck success-progress on fuel efficiency and market adoption. Report DOE/EE-1419. https://www.energy.gov/sites/prod/files/2016/06/f33/EERE_

SuperTruck_FS_R121\%20FINAL.pdf. Accessed 18 June 2021

11. Verbeek M, van Gijlswijk R, van Zyl S, et al (2018) Assessments with respect to the EH HDV Co2 legislation. TNO report 2018 P10214. TNO, Delft. http://resolver.tudelft.nl/uuid:cdc11c451636-431a-8016-5f582769c1c3. Accessed 18 June 2021

12. Delgado O, Rodriguez F (2018) $\mathrm{CO}_{2}$ emissions and fuel consumption standards for heavy-duty vehicles in the European Union. The International Council on Clean Transportation, Briefing Note. https://theicct.org/publications/co2-emissions-andfuel-consumption-standards-heavy-duty-vehicles-europeanunion. Accessed 18 June 2021

13. Meijer M, Grover B (2020) Development and demonstration of advanced engine and vehicle technologies for class 8 heavy-duty vehicle (SuperTruck II). DOE Annual Merit Review Presentation, ID ACS124. https://www.energy.gov/sites/prod/files/2020/05/ f75/ace124_meijer_2020_o_4.30.20_120PM_TDM.pdf. Accessed 18 June 2021

14. Ciglar J, Oppermann, D (2020) Navistar SuperTruckII development and demonstration of a fuel-efficient class 8 tractor \& trailer. DOE Annual merit Review Presentation, ID ACE103. https://www.energy.gov/sites/prod/files/2020/05/f75/ace103_ zukouski_2020_o_4.27.20_108PM_LR.pdf. Accessed 18 June 2021

15. Dickson J, Damon K (2020) Annual merit review cummins/ Peterbilt SuperTruckII. DOE Annual merit Review Presentation, ID ACE102. https://www.energy.gov/sites/prod/files/2020/05/ f75/ace102_dickson_2020_o_5.20.20_427PM_LR.pdf. Accessed 18 June 2021

16. Amar P, Li J (2020) Volvo SuperTruck 2-pathway to cost-effective commercialized freight efficiency. DOE Annual Merit Review Presentation, ID ACE101. https://www.energy.gov/sites/ default/files/2020/05/f75/ace101_amar_2020_o_4.29.20_ 1135AM_JL.pdf. Accessed 18 June 2021

17. McDonnell G (2015) Locomotives: the modern diesel \& electric reference. Boston Mills Press, Boston

18. Oliver B (2020) Environment \& Climate Change Canada Contract No. 30000704788 - Assessment of the Design, Deployment Characteristics and Requirements of a Hydrogen Fuel Cell Powered Switcher Locomotive. Oakville, ON, Canada: Change Energy Services Inc.

19. TrainWeb, RJ Corman Railpower. http://www.trainweb.org/ gensets/railpower.html. Accessed 4 Feb 2021

20. Krok A (2021) Navistar, GM, OneH2 combine forces for longhaul hydrogen-electric trucks. Roadshow. https://www.cnet.com/ roadshow/news/navistar-gm-oneh2-long-haul-hydrogen-electrictrucks/. Accessed 18 June 2021

21. Toyota (2020) Toyota and hino to jointly develop class 8 fuel cell electric truck for North America. https://global.toyota/en/ newsroom/corporate/34009225.html. Accessed 18 June 2021

22. Ballard Power Systems Inc (2019) Ballard next-gen fuel cell modules to power freight trucks in Canadian hydrogen project. https://www.ballard.com/about-ballard/newsroom/news-releases/ 2019/05/07/ballard-next-gen-fuel-cell-modules-to-power-freighttrucks-in-canadian-hydrogen-project. Accessed 18 June 2021

23. Talebian H, Herrera O, Tran M, Merida W (2018) Electrification of road freight transport: policy implications in British Columbia. Energy Policy 115:109-118

24. Kast J, Morrison G, Gangloff JJ et al (2018) Designing hydrogen fuel cell electric trucks in a diverse medium and heavy duty market. Res Transp Econ 70:139-147

25. Lee DY, Elgowainy A, Kotz A et al (2018) Life-cycle implications of hydrogen fuel cell electric vehicle technology for medium- and heavy-duty trucks. J Power Sour 393:2177-2229

26. Cabukoglu E, Georges G, Kung L et al (2019) Fuel cell electric vehicles: an option to decarbonize heavy-duty transport? Results from a Swiss case-study. Transp Res Part D: Transp Environ 70:35-48

27. Hirschlag A (2020) Next stop, hydrogen-powered trains, BBC Future Planet. https://www.bbc.com/future/article/20200227how-hydrogen-powered-trains-can-tackle-climate-change. Accessed 29 Oct 2020

28. Jang B (2021) Ballard shares surge after train deal amid hydrogen industry rally. The Globe and Mail. https://www. theglobeandmail.com/business/article-ballard-shares-surge-aftertrain-deal-amid-hydrogen-industry-rally/. Accessed 13 Jan 2021

29. Stasko R, Harvey R, Norris C, Heulitt N (2020) Hydrail: the future of rail electrification across Canada. Canadian Smart Rail Technology Conference 2020 - CUTRIC, November 23-24 2020. virtual, online.

30. Villeneuve D, Girbach J (2020) Improving transportation efficiency through integrated vehicle, engine, and powertrain research - Supertruck 2. DOE Annual Merit Review Presentation, ID ACE100. https://www.energy.gov/sites/prod/files/2020/05/ f75/ace100_Villeneuve_2020_o_4.29.20_250pm_TDM.pdf. Accessed 18 June 2021 
31. European Union (2014) Commission Regulation (EU) No 133/2014. Official Journal of the European Union. https://eur-lex. europa.eu/legal-content/EN/TXT/?uri=celex\%3A32014R0133. Accessed 18 June 2021

32. US Environmental Protection Agency (2001) Control of Air Pollution from New Motor Vehicles: Heavy-Duty Engine and Vehicle Standards and Highway Diesel Fuel Sulfur Control Requirements. 40 CFR Parts 69, 80 and 86. https://www.govinfo. gov/content/pkg/FR-2001-01-18/pdf/01-2.pdf. Accessed 18 June 2021

33. US Environmental Protection Agency (2016) Final rule for phase 2 greenhouse gas emissions standards and fuel efficiency standards for medium- and heavy-duty engines and vehicles. $40 \mathrm{CFR}$ Part 9. https://www.gpo.gov/fdsys/pkg/FR-2016-10-25/pdf/201621203.pdf. Accessed 18 June 2021

34. European Union (2019) Regulation (EU) 2019/1242. http://data. europa.eu/eli/reg/2019/1242/oj. Accessed 18 June 2021

35. California Air Resources Board (CARB) (2020) Carbon intensity values of certified pathways. Updated Dec 31, 2020. https://ww2. arb.ca.gov/resources/documents/lcfs-pathway-certified-carbonintensities. Accessed 18 June 2021

36. Alleman A, McCormik R (2016) Biodiesel handling and use guide, 5th ed. US Department of Energy. DOE/GO-102016-4875. https://afdc.energy.gov/files/u/publication/biodiesel_handling use_guide.pdf. Accessed 18 June 2021

37. Schenk PM, Thomas-Hall SR, Stephens E et al (2008) Second generation biofuels: high-efficiency microalgae for biodiesel production. BioEnergy Res 1:20-43. https://doi.org/10.1007/ s12155-008-9008-8

38. Pinney C, Smith B (2013) Cost-benefit analysis of alternative fuels and motive designs. Federal Railroad Association, US Department of Transportation. Report DOT/FRA/ORD-13/21. https://railroads.dot.gov/sites/fra.dot.gov/files/fra_net/3128/CostBenefit $\% 20$ Analysis $\% 20$ Alternative $\% 20$ Fuels $\% 20$ and $\%$ 20Motive\%20Designs_20130424_final.pdf. Accessed 18 June 2021

39. Murta AL, De Freitas M, Ferreira C et al (2021) The use of palm oil biodiesel blends in locomotives: an economic, social and environmental analysis. Renew Energy 164:521-530

40. Stead C, Wadud Z, Nash C, Li H (2019) Introduction of biodiesel to rail transport: lessons from the road sector. Sustainability 11(3):904

41. Fritz SG (2000) The potential for LNG as a railroad fuel in the US. ASME J Eng Gas Turbines Power 122(1):130-134

42. Lenz M (2014) Natural gas goes on trial. Int Railw J https://www. railjournal.com/in_depth/natural-gas-goes-on-trial. Accessed 18 June 2021

43. Nott D (N.d.) MK1200G LNG. http://www.lngplants.com/ mk1200G.htm. Accessed 07 Feb 2021

44. Smith I, Briggs T, Sharp C, Webb C (2017) Achieving 0.02 g/bhp-hr NOx Emissions from a Heavy-Duty Stoichiometric Natural Gas Engine Equipped with Three-Way Catalyst. SAE Technical Paper 2017-01-0957. https://doi.org/10.4271/2017-010957

45. Thomas B (2015) LNG for locomotives; GE's NextFuel Retrofit Kit. https://naturalgasnow.org/lng-for-locomotives-gas-nextfuelretrofit-kit/. Accessed 18 June 2021

46. Sommer DE, Yeremi M, Son J et al (2019) Characterization and reduction of in-use $\mathrm{CH} 4$ emissions from a dual fuel marine engine using wavelength modulation spectroscopy. J Environ Sci Technol. https://doi.org/10.1021/acs.est.8b04244

47. Intergovernmental Panel on Climate Change (2014) Climate Change 2014 Synthesis Report. Contribution of Working Groups I, II and III to the Fifth Assessment Report of the Intergovernmental Panel on Climate Change [Core Writing Team, R.K. Pachauri and L.A. Meyer (eds.)]. IPCC, Geneva, Switzerland
48. Volvo (2017) New trucks from Volvo running on gas. https:// www.volvogroup.com/en-en/news/2017/oct/news-2687745.html. Accessed 18 June 2021

49. McTaggart-Cowan G, Mann K, Huang J, Singh A, Patychuk B, Munshi SR (2015) Direct injection of natural gas at 600 bar in a pilot-ignited, heavy-duty engine. SAE Int J Engines 8(3):981-996

50. Ouellette P, Goudie D, McTaggart-Cowan G (2016) Progress in the development of natural gas HPDI for Euro VI heavy-duty trucks. In: Liebl J, Beidl C (eds) Internationaler Motorenkongress 2016. Proceedings. Springer Vieweg, Wiesbaden. https://doi.org/ 10.1007/978-3-658-12918-7_45

51. Vermeulen R (2019) Emissions testing of a Euro VI LNG-diesel DF truck. TNO report R10193. https://publications.tno.nl/ publication/34633965/p17KqC/TNO-2019-R10193.pdf. Accessed 18 June 2021

52. Progress Rail (N.d.) Natural gas solutions. www.progressrail. com/en/Segments/Engines/Natural_Gas_Solutions.html. Accessed 22 Jan 2021

53. Smith K (2014) Westport delivers first LNG tender to EMD. Railway Age. https://www.railwayage.com/freight/class-i/ westport-delivers-first-lng-tender-to-emd/. Accessed 18 June 2021

54. Chart Industries (2017) Case Study LNG \#17 Rail - LNG Tender Car. http://files.chartindustries.com/21168430_Rail_ LNGTenderCar_CS17.pdf. Accessed 18 June 2021

55. Westport Fuel Systems (2021) Westport fuel systems to cooperate with truck and bus manufacturer scania on a direct injected hydrogen engine research project. https://wfsinc.com/newsreleases/2021/to-cooperate-with-truck-and-bus-manufacturerscania-on-a-direct-injected-hydrogen-engine-research-project. Accessed 18 June 2021

56. Dimitriou P, Kuma M, Tujimura T, Suzuki Y (2018) Combustion and emission characteristics of a hydrogen-diesel dual fuel engine. Int J Hydrog Energy 43:13605-13617

57. Li H, Liu S, Liew C, Gatts T, Wayne S, Clark N, Nuszkowski J (2017) An investigation of the combustion process of a heavyduty dual fuel engine supplemented with natural gas or hydrogen. Int J Hydrog Energy 42:3352-3362

58. Wang L, Liu D, Yang Z, Li H, Wei L, Li Q (2018) Effect of H2 addition on combustion and exhaust emissions in a heavy-duty diesel engine with EGR. Int J Hydrog Energy 43:22658-22668

59. El Hannach M, Ahmadi P, Guzman L, Pickup S, Kjeang E (2019) Life cycle assessment of hydrogen and diesel dual-fuel class 8 heavy duty trucks. Int J Hydrog Energy 44:8575-8584

60. Spiriyagin M, Wolfs P, Cole C, Spiryagin V, Sun YQ, McSweeney T (2017) Chapter 2: Heavy haul locomotives and their design. In: Vantsevich VV (ed) Design and simulation of heavy haul locomotives and trains. CRC Press

61. Bombardier Transportation (2009) TRAXX 4 EnvironmentEnvironmental Product Declaration: TRAXX F140 MS. https:// web.archive.org/web/20090707035846/http://www.bombardier. com/files/en/supporting_docs/TRAXX_MS_EMAS.pdf. Accessed 24 Jan 2021

62. Scott DS, Rogner HH, Scott MB (1993) Fuel cell locomotives in Canada. Int J Hydrog Energy 18:253-263

63. Cuda P, Dincer I, Naterer GF (2012) Hydrogen utilization in various transportation modes with emissions comparisons for Ontario, Canada. Int J Hydrog Energy 37:634-643

64. Cummings A (2020) CP releases climate change statement; reiterates commitment to sustainability. CISION. https://www. cpr.ca/en/media/cp-releases-climate-change-statement-reiteratescommitment-to-sustainability. Accessed 20 Jan 2021

65. Heid B, Hart D (2020) Sustainability and clean tech analysis. In: National bank financial annual energy conference, Toronto, January 21, 2020 
66. Corneil E R (1977) Canadian railway electrification study: phase I. In: Conference on railroad electrification: the issues, Washington, DC, USA, 13-15 June 1977

67. Motor Transport Association - Emissions Reduction Alberta (2020) Alberta Zero Emissions Truck Electrification Collaboration (AZETEC). https://eralberta.ca/projects/details/alberta-zeroemissions-truck-electrification-collaboration-azetec/. Accessed 20 Jan 2021

68. Harvie A, Collett M, Smeijers G, Devost M (2020) Canada to increase carbon taxes by $566 \%$. Norton Rose Fulbright. https:// www.nortonrosefulbright.com/en/knowledge/publications/ d58ef644/canada-to-increase-carbon-taxes-by-566?utm_source= ground.news\&utm_medium=referral. Accessed 20 Jan 2021

69. GE Research (2020) Trip optimizer for railroads. https://www.ge. com/research/project/trip-optimizer-railroads. Accessed 20 Jan 2021

70. Ycharts (2021) US retail diesel price. https://ycharts.com/ indicators/us_retail_diesel_price. Accessed 11 Jan 2021

71. Collins L (2020) A wake-up call on green hydrogen: the amount of wind and solar needed is immense. RECHARGE - Global news and intelligence for the Energy Transition. https://www. rechargenews.com/transition/a-wake-up-call-on-green-hydrogenthe-amount-of-wind-and-solar-needed-is-immense/2-1-776481. Accessed 20 Jan 2021

72. Hoffrichter A (2019) Hydrogen-rail (hydrail) development. In: H2@Rail Workshop, Lansing, Michigan, 26-27 March 2019

73. Miller A R, Shumway W E (2018) Vehicle Projects Inc. http:// www.vehicleprojects.com/\#: :text=Vehicle\%20Projects\% 20 Inc $\% 20$ is $\% 20$ the, and $\% 20$ personnel $\% 20$ of $\% 20$ the $\%$ 20nonprofit. Accessed 20 Jan 2021

74. Lambrecht TJ, Miller AR, Hess KS, Erickson TL, Dippo JL (2010) Testing of the BNSF fuel-cell switch locomotive: part 2. In: Proceedings of the Locomotive Maintenance Officers Association (LMOA) Annual Meeting, Montreal, Quebec, Canada, 18-19 October 2010

75. Woodrow S (2020) CP Announces Hydrogen-Powered Locomotive Pilot Project. CP Investor News. https://investor.cpr.ca/ news/press-release-details/2020/CP-announces-hydrogenpowered-locomotive-pilot-project/default.aspx. Accessed 20 Jan 2021 